\title{
AC Electric Conductivity and Biochemical Analyses of Physiologic Solutions to Follow Biomimetic Coatings on Corals Impregnated with Ag or Zn or Sr Ions
}

\author{
W.I. Abdel-Fattah ${ }^{*}$, , A.M. Sallam², I.H. Ibrahim² and H. Ibrahim² ${ }^{2}$ \\ ${ }^{I}$ Biomaterials Department, National Research Centre, Cairo, Egypt \\ ${ }^{2}$ Research Assistant, Biophysics Department, Ain-Shams University, Cairo, Egypt
}

\begin{abstract}
The impregnation of sodium hypochlorite ( $\mathrm{NaOCl}$ ) treated corals (Favia Stelligera) from Red Sea coast, Egypt with two moles of either divalent $\left(\mathrm{Sr}^{2+}, \mathrm{Zn}^{2+}\right)$ or mono valent $\left(\mathrm{Ag}^{+}\right)$ions for 6 hours at ambient conditions was performed. Subsequent effect on hydroxyapatite (HA) deposition upon immersion in saline and simulated body fluid (SBF) solutions up to $72 \mathrm{~h}$ was followed through measuring room temperature Ac-electrical conductivities solutions during immersion periods. The changes in the levels of Calcium $\mathrm{Ca}^{2+}$ and inorganic phosphorous iP in SBF were followed by spectrophotometer post $72 \mathrm{~h}$ immersion using biochemical kits in both solutions. The microstructures of the impregnated corals were examined using Scanning electron microscope (SEM) and Energy dispersive X-ray analysis (EDX) compared to the control treated with $\mathrm{NaOCl}$.

Various levels of $\mathrm{Ca}^{2+}$ and iP in SBF were obtained in the trend of more HA deposition. Massive Carbonated hydroxyapatite (CHA) formation was achieved proving biolayer formation. The samples possess intermediate porosity of $17 \%$ with interconnectivity and architectures similar to bone. It was found that the immersion of impregnated samples in SBF formed HA which differed according to the valency of the ions and its effect on morphology.

Therefore, the samples are suggested as hard tissue engineered constructs that possess antimicrobial effect and/or bone seeking function to reduce implant infection and enhance bone formation.
\end{abstract}

Keywords: Corals, $\mathrm{Sr}^{2+}, \mathrm{Zn}^{2+}$ or $\mathrm{Ag}^{+}$ions impregnation, $\mathrm{AC}$ electrical conductivity, $\mathrm{SBF}$ immersion, Biochemical analysis, Biomimitic deposition, SEM, EDX.

\section{INTRODUCTION}

In the year 2010, over 52 million women and men aged 50 and over will be affected by osteoporosis and this number will climb to over 61 million by the year 2020 [1]. Bone grafting is used to promote bone fussing in fully detached fractures, in arthrodesis of joint, and to fill defects or cavities in bone. Grafts involve transplantation of bone from either another part of person's body (auto graft), from another human patient (allograft), or even an animal (xenograft).

Biomaterials may provide a solution to these problems; an ideal bone substitute should be tolerated by the host tissue without any adverse reaction. It should promote bone formation, have appropriate mechanical strength, be malleable and resorbs after it has fulfilled its function [2]. The purpose of a biomaterial is to replace part or perform function of the body in a safe, reliable, economic and physiologically acceptable manner

Complex forms based on natural structures that can mimic natural scaffolds offer an exciting range of avenues for the construction of a bone analog for tissue engineering

*Address correspondence to this author at the Biomaterials Dept. National Research Centre, Dokki, Cairo, Egypt; Tel: 020101407566; Fax: 00202 33370931; E-mail: nrcfifi@yahoo.com taking the advantage of tridimensional constructs to deliver vital cells to the damaged sites [3].

Marine corals act as bioactive natural materials because they are biocompatible, biodegradable and osteoconductive materials. Corals from various sources have been shown to have cell attachment, spread, proliferation and differentiation [4]. Although having strength perse, it is a biodegradable material that bonds tightly to bone without surface apatite layer. On other hand, natural corals provide mechanical interlocking bonding provided by the anchoring effect of the newly formed bone into the surface roughness could be considered as a major factor in bone bonding. Both $\beta$ Tricalcium phosphate ( $(-\mathrm{TCP})$ and natural calcite do not have apatite formation on their surfaces in $\operatorname{SBF}[5,6]$ but despite of this, they bond to living bone. These results may be related to the high resorbability of these materials. In contrast, natural abalone shell forms apatite form on its surface in SBF [7] but does not bond to living bone which might be attributed to antibody reaction to protein in the shell.

It was thought to beneficially modify corals by impregnating them with ions such as Silver $\left(\mathrm{Ag}^{+}\right)$which is reported to induce antibacterial and antimicrobial effect upon substitution with hydroxyapatite ceramics. While Strontium $\left(\mathrm{Sr}^{2+}\right)$ and $\mathrm{Zinc}\left(\mathrm{Zn}^{2+}\right)$ are proved as bone seeking elements.

Various investigations have been performed to develop 
antibacterial surface coating. Among them Kim, T. N., used the antimicrobial ceramics based on $\mathrm{HA}$ with additions of $\mathrm{AgNO}_{3}$, $\mathrm{Cu}\left(\mathrm{NO}_{3}\right)_{2} \cdot 3 \mathrm{H}_{2} \mathrm{O}$ and $\mathrm{Zn}\left(\mathrm{NO}_{3}\right)_{2} \cdot 6 \mathrm{H}_{2} \mathrm{O}$. He proved that $\mathrm{Ag}^{+}$ HA exhibited complete inhibition of the growth of E-coli after 20h incubation. In contrast to $\mathrm{Ag}^{+} \mathrm{HA}$, the $\mathrm{Cu}^{2+}$ and $\mathrm{Zn}^{2+} \mathrm{HA}$ didn't show any antimicrobial effect in his experiment. This implied that the $\mathrm{Ag}^{+} \mathrm{HA}$ plays an important role in the inhibition of the growth of E-coli [8]. Also Abou Neel, E. A. et al. used copper oxide $(\mathrm{CuO})$ - containing phosphate based glass fibers (PGF) for potential uses in wound healing with several concentrations of $\mathrm{CuO}(0,1,5,10$ mole $\%)$. They found that the addition of $\mathrm{CuO}$ into the glass fibers was effective in reducing the number of bacteria attached to the fiber and fibers with $10 \%$ mole $\mathrm{CuO}$ were most effective in delivering sufficient amounts of antibacterial $\mathrm{Cu}^{2+}$ to prevent colonization and reduce the number of viable bacteria in the local environment [9]. However, Heidenau, F, made a comparative study about the antibacterial potential of different metal ions $\mathrm{Cu}^{2+}, \mathrm{Ag}^{+}, \mathrm{Co}^{2+}$, $\mathrm{Zn}^{2+}, \mathrm{Al}^{3+}$ and $\mathrm{Hg}^{2+}$ with respect to both cytotoxicity (tissue cell toxicity) and antibacterial properties. He reported that the growth inhibition tests proved that $\mathrm{Ag}^{+}$as well as $\mathrm{Zn}^{2+}$ and $\mathrm{Hg}^{2+}$ ions exhibit very strong cytotoxicity at low concentration but $\mathrm{Co}^{2+}$ showed intermediate mode whereas tissue cells tolerated relatively high concentration of $\mathrm{Cu}^{2+}$ and $\mathrm{Al}^{3+}$. These results are similar for bacteria, except the fact that $\mathrm{Co}^{2+}$ and $\mathrm{Zn}^{2+}$ exhibited no significant antibacterial effect at the investigated concentrations and that $\mathrm{Cu}^{2+}$ ions were significantly more effective against bacteria, staphylococcus epidermis, than toxic for tissue cells. The concentration reported for each ion was $\left(\mathrm{Ag}^{+}=3.5 \times 10^{-3}, \mathrm{Zn}^{2+}=3.6 \times 10^{-3}, \mathrm{Hg}^{2+}=4.2 \times 10^{-3}, \mathrm{Cu}^{2+}=2\right.$. $3 \times 10^{-1}, \mathrm{Co}^{2+}=3.4 \times 10^{-2}$ and $\left.\mathrm{Al}^{3+}=1.8 \times 10^{-2} \mathrm{mmol} / \mathrm{L}\right)$. So copper ions prove most adequate to equip implant surfaces with antibacterial properties without decreasing their biocompatibility in a significant manner [10]. However, none of them followed the consequent effect on the apatite deposition.

In a previous work deprotinated corals were impregnated with $\mathrm{Cu}^{2+}$ in various mole concentrations between 0.5 to2. 0 and proved that the higher $\mathrm{Cu}^{2+}$ concentration affect the more dense surface biolayer formation [11].

In several reports as early as 1991, it was proposed that the essential requirements for an artificial material to bond to living bone is the formation of bone like apatite on its surface when implanted in the living body, and that this in vivo apatite formation can be reproduced in a simulated body fluid (SBF) with ion concentrations nearly equal to those of human blood plasma [12 ]. This means that the in vivo bone bioactivity of a material can be predicted from the apatite formation on its surface in SBF. Since then, in vitro bone bioactivity of various types of materials have been evaluated through apatite formation in SBF. However, the validity of this method has not been systematically assessed. So to investigate the mechanism of the material/ tissue reaction in vitro examination, with $\mathrm{SBF}$ has been developed [13]. In 2003, Conventional SBF with the refined recipe was proposed to the technical Committee ISO/TC150 of International Organization for standardization for in the vitro measurement of apatite forming ability of implant materials and is being discussed by the committee [14].

The aim of the present work is dealing with the impregnation of corals with either of $\mathrm{Ag}^{+}, \mathrm{Zn}^{2+}$ or $\mathrm{Sr}^{2+}$ ions in 2 moles concentrations each. The assessment of ions mobility and therefore, biocompatibility of corals in biological solutions was followed through AC electrical conductivity measurements using Conductance Bridge. Spectrophotometer and chemical Kits were used to analyze biological solutions pre and post immersion up to $72 \mathrm{~h}$. The results are supposed to reflect ion mobility and subsequent biolayer formation on coral surfaces. The validity of $\mathrm{AC}$ electrical conductivity using conductance bridge and ion mobility of saline or SBF as a tool for studying the kinetics of bioactive layer formed compared to spectral analysis using biochemical kits was verified. Moreover, the formation of carbonated hydroxyapatite biolayer and other phosphates on the surface are studied by Scanning Electron microscope equipped with X-ray analysis (SEM and EDX)for the samples post $72 \mathrm{~h}$ immersion.

\section{EXPERIMENTAL PROCEDURES}

\subsection{Materials}

Coral samples Favia stelliger were collected from Red Sea coast, Hurgada, Egypt. Samples preparation and deproteination with $3 \%$ sodium hypochlorite $\mathrm{NaOCl}$ and characterization were previously reported [15].

\subsection{Impregnating Solutions}

Three impregnating solutions of different ions $\mathrm{Ag}^{+}, \mathrm{Zn}^{2+}$, and $\mathrm{Sr}^{2+}$ with similar concentrations of 2.00 moles each were prepared by dissolving 33. 8, 29. 0 and 21. $0 \mathrm{~g}$ of each of silver Nitrate $\left[\mathrm{AgNO}_{3}\right]$ (Laboratory Rasayan), Zinc Nitrate $\left[\mathrm{Zn}\left(\mathrm{NO}_{3}\right)_{2} .6 \mathrm{H}_{2} \mathrm{O}\right]$ (Laboratory Rasayan) and Strontium Nitrate $\left[\mathrm{Sr}\left(\mathrm{NO}_{3}\right)_{2}\right]$ (Laboratory Rasayan) in $50 \mathrm{ml}$ bidistilled water respectively and kept for impregnation experiments.

The Cleaned Coral samples having similar porosity $(17 \%)$ were impregnated with each specific ion. A ratio 1: 10 wt/vol. was maintained for 6 hours at room temperature. Samples were then removed and dried at $90^{\circ} \mathrm{C}$ overnight in a dryer. Previous work proved optimum conditions of $17 \%$ porosity and 2 moles of $\mathrm{Cu}^{2+}$ ions impregnation for $6 \mathrm{hrs}$ [11].

\subsection{Immersion in Physiologic Solutions}

\subsubsection{Immersion in Saline}

A Saline solution was prepared by dissolving $0.9 \mathrm{gm}$ of Sodium Chloride $(\mathrm{NaCl})$ (ADWIC) in $100 \mathrm{ml}$ bidistilled water [16] and used to follow ionic movement during immersion of ion /impregnated solid corals.

\subsubsection{Immersion in $S B F$}

Corrected SBF solution was prepared according to Kokubo [14] by dissolving chemicals in ion exchanged and distilled water buffered at $\mathrm{pH}=7.5$ at $37^{\circ} \mathrm{C}$. The samples were immersed with a ratio of (1: 10) $\mathrm{S} / \mathrm{L}$ for $72 \mathrm{~h}$ at room temperature without agitation or renewal of solutions. Samples were removed from solutions post $72 \mathrm{~h}$, washed with bidistilled water and dried $\left(90^{\circ} \mathrm{C}\right)$ over night.

The Saline and SBF solutions left post $72 \mathrm{~h}$ immersion were kept for biochemical analysis while the solids were dried and examined by SEM equipped with EDX. 


\subsubsection{Bioactivity Assessment}

\subsection{3.a. AC Electrical Conductivity}

To predict the mechanism of coral-tissue interaction in vitro, Corals were soaked either in saline or SBF filled in a Conductance Bridge which was used to follow any changes in saline or r-SBF during 72 hours soaking. The variations in conductivity due to the effect of releasing or absorbing ions to/or from the biological solutions were recorded.

\subsection{3.b. Biochemical analysis}

\section{i. Calcium and Phosphorous Contents}

Subsequent effect of ions impregnation on CHA surface deposition was followed post $72 \mathrm{~h}$ immersion in both Saline and SBF solution. The level of ionized Calcium and phosphorous in both saline and SBF post $72 \mathrm{~h}$ were measured using biochemical kits (Centronic $\mathrm{GmbH}-$ Germany kits) and spectrophotometer (Jenway LTD- U. K.). The levels measured were cumulative as the media were not replaced, so the values determined reflect the changes occurring post $72 \mathrm{hrs}$.

\section{ii Silver, Zinc and Strontium Ions}

Both treated control /coral and impregnated/ coral (1gm each)were dissolved in $10 \mathrm{ml}$ of $\mathrm{HCl}(10 \%$ of $\mathrm{HCl})$. The strontium, silver and zinc content were measured using atomic absorption spectrophotometer (Perkin Elmer) The recommended flame used was air-acetylene, oxidine ( USA model 3100).

\subsection{3.c. Surface Morphology}

The surfaces of the impregnated corals post SBF immersion were examined after coating with gold as an adhesive and conductor. The formation of (CHA) biolayer on the surfaces was verified by scanning electron microscopy with X-ray analysis SEM equipped EDX (Philips XL30).

\section{RESULTS AND DISCUSSION}

\subsection{Electrical Conductivity}

\subsubsection{Saline}

The recorded conductivity values are within the range of $120-170 \times 10^{-2} \mathrm{ohm}^{-1}$. $\mathrm{cm}^{-1}$. Coral samples of similar porosities and impregnated with similar ionic concentrations of 2 moles of each of $\mathrm{Sr}^{2+}, \mathrm{Zn}^{2+}$ or $\mathrm{Ag}^{+}$possess increased $\mathrm{AC}$ conductivity values during the soaking periods up to $72 \mathrm{~h}$ (Fig. 1). Within the initial $10 \mathrm{hrs,} \mathrm{sharp} \mathrm{increase} \mathrm{is} \mathrm{recorded}$ for $\mathrm{Zn} /$ coral to reach a plateaux as early as $26 \mathrm{hrs}$ denoting structure stability. The enhanced values of $\mathrm{Zn} /$ coral as early as $12 \mathrm{~h}$ are followed by a single plateaux as early as $12 \mathrm{~h}$ and are followed by a single plateau till $72 \mathrm{~h}$ denoting structural stability and completion of exchange. The values increase due to ionic release from corals following the order of $\mathrm{Zn}^{2+}>$ $\mathrm{Sr}^{2+} .>\mathrm{Ag}^{+} /$coral which continued between $20-55 \mathrm{~h}$. At $60 \mathrm{~h}$ and above the order changed to follow $\mathrm{Sr}^{2+}>\mathrm{Zn}^{2+}>\mathrm{Ag}^{+} /$coral possibly due to exchange with some other ions. On the other hand, $\mathrm{Sr}^{2+}$ and $\mathrm{Ag} / \mathrm{coral}$ have their conductivity values which exhibit several plataux denoting stepwise increase of conductivity in parallel with released ions from corals.

\subsubsection{SBF}

The conductivity values are within the range of 0.5 to 25 $\mathrm{x} 10^{-2} \mathrm{ohm}^{-1} . \mathrm{cm}^{-1}$ which decrease with time and prove, therefore, the ionic deposition on coral surfaces which differed according to ionic species. Such reduced values with time prove ionic deposition from SBF on coral surfaces. Initially the conductivity values of SBF follow the order of $\mathrm{Sr}^{2+}>\mathrm{Zn}^{2+}>$ $\mathrm{Ag}^{+}$up to $42 \mathrm{~h}$ (Fig. 2). As this ionic sequence is similar to saline but in an opposite direction, therefore an involvement in ionic deposition is proved. Measurements at early hours prove that values of $\mathrm{Zn} /$ coral are reduced from32 to $2 \times 10^{-2} \mathrm{ohm}^{-1}$. $\mathrm{cm}^{-1}$ up to $48 \mathrm{~h}$ and above. The stability of ionic exchange is reached by $\mathrm{Sr} /$ coral as early as $20 \mathrm{~h}$ which is prolonged to $35 \mathrm{~h}$ for $\mathrm{Ag} /$ coral and to $58 \mathrm{~h}$ for $\mathrm{Zn} /$ coral. The values of conductivity corresponding to $\mathrm{Ag} / \mathrm{coral}$ are reduced tremendously at $10 \mathrm{~h}$ to reach one third of its initial value proving ionic deposition. Such trend continued to acquire stability at 35 and above proving completion of deposition.

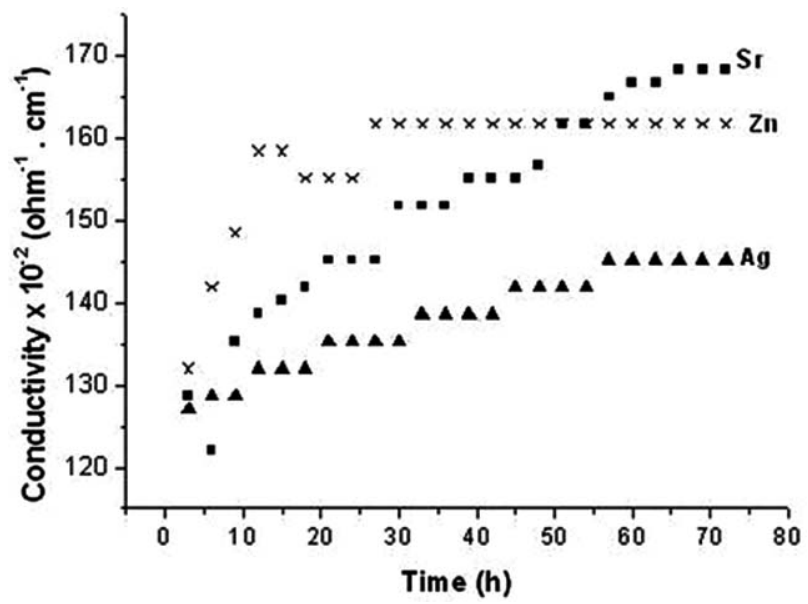

Fig. (1). The electrical conductivity of saline incubating corals with different ions during 72 hours immersion.

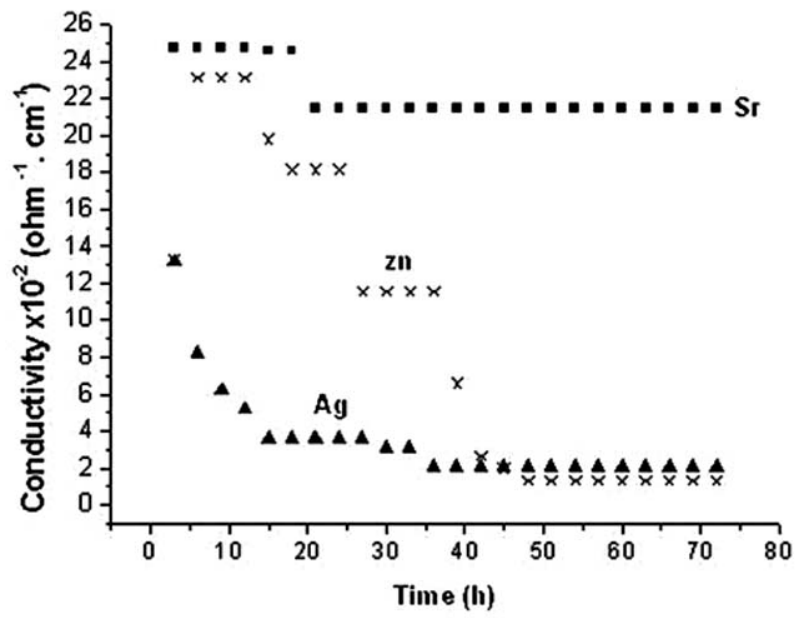

Fig. (2). The electrical conductivity of SBF incubating corals with different ions during $72 \mathrm{~h}$ immersion.

\subsection{Biochemical measurements}

\subsubsection{Saline}

Analyses of saline from different cation /impregnated corals after $72 \mathrm{~h}$ soaking prove the high release of iP from 
$\mathrm{Sr} /$ coral is turned to absorption for $\mathrm{Ag} /$ and $\mathrm{Zn} /$ coral (Fig. 3). $\mathrm{A}$ reverse behavior of $\mathrm{Ca}^{2+}$ which is highest for $\mathrm{Ag} /$ coral followed by $\mathrm{Zn} /$ and $\mathrm{Sr} /$ coral with a net result of highest conductivity for $\mathrm{Sr} /$ coral. Ionic exchange is to be expected for divalent cations of $\mathrm{Sr}$ and $\mathrm{Ca}$ between impregnated coral surface and ions in the SBF media consisting of positive and negative ions as well. The order of $\mathrm{Ca}$ deposition would be the reverse of its values in SBF following the trend of $\mathrm{Sr}>\mathrm{Zn}>$ control $>\mathrm{Ag}$ which is coinciding with the electric conductivity of the saline solutions containing impregnated corals.

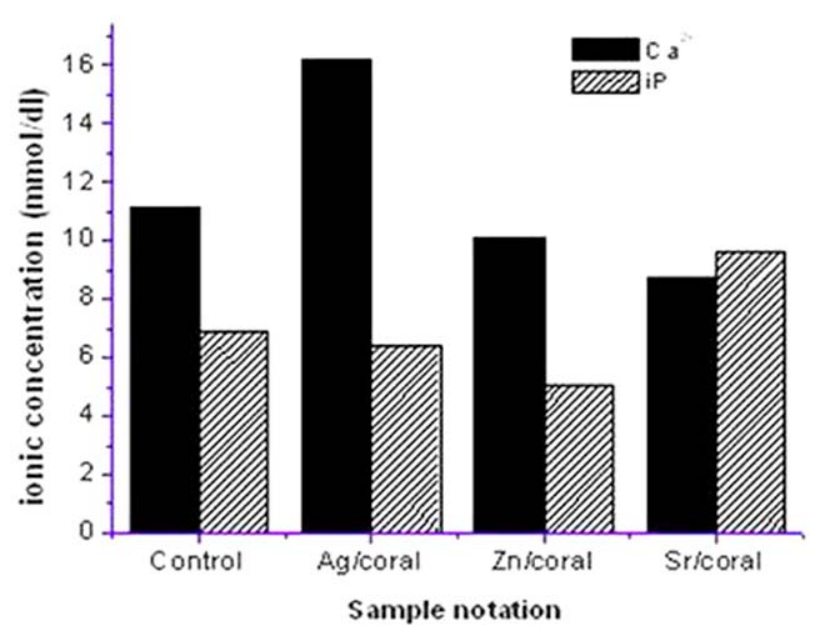

Fig. (3). The Concentration of $\mathrm{Ca}^{2+}$, iP in saline post $72 \mathrm{~h}$ soaking of coral with $17 \%$ porosity.

\subsection{2. $S B F$}

Analyses of SBF left after $72 \mathrm{~h}$ incubating the impregnated corals reveal the enhanced values of $\mathrm{Ca}^{2+}$ and iP compared to control/coral with an order of $\mathrm{Ag}>\mathrm{Zn}>\mathrm{Sr}$ for $\mathrm{Ca}$ ${ }^{2+}$ while an order of $\mathrm{Sr}>\mathrm{Ag}>\mathrm{Zn}$ is followed for iP.

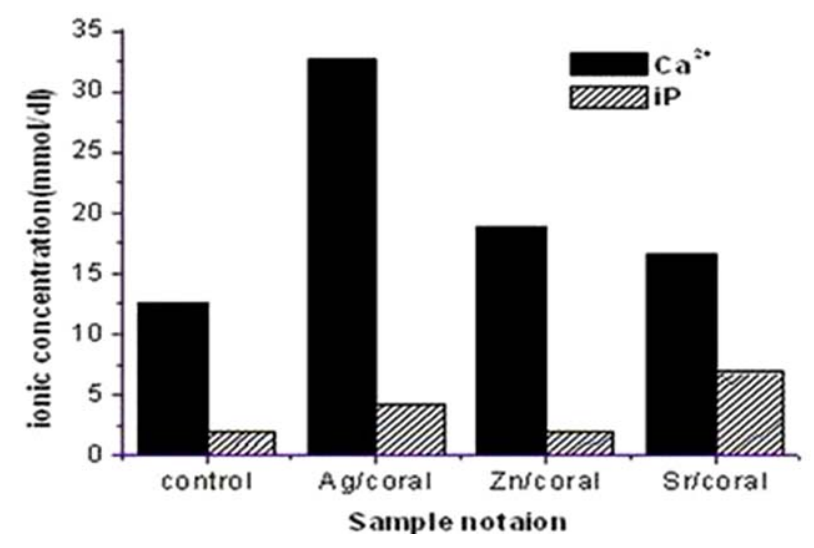

Fig. (4). The Concentration of $\mathrm{Ca}^{2+}$, iP in SBF post $72 \mathrm{hrs}$ soaking of coral with $17 \%$ porosity.

Interesting is the behaviour of control coral which adsorbs $\mathrm{Ca}^{2+}$ from SBF and iP to a higher extent which is the due to the positively charged surface of the corals (Fig. 4). These trends are similar to those encountered in saline but the values are nearly doubled. Therefore, all the samples prove release of these ions which are adsorbed on the coral surface to be involved in the surface formed apatitic phases. . The ionic release of $\mathrm{Ca}^{2+}$ from impregnated corals is nearly double the values recorded for saline proving its higher adsorption at earlier periods of than $72 \mathrm{~h}$. On the other hand, iP values being slightly lower are pointing to its adsorption on the coral surfaces due to its positively charged surface.

(a)

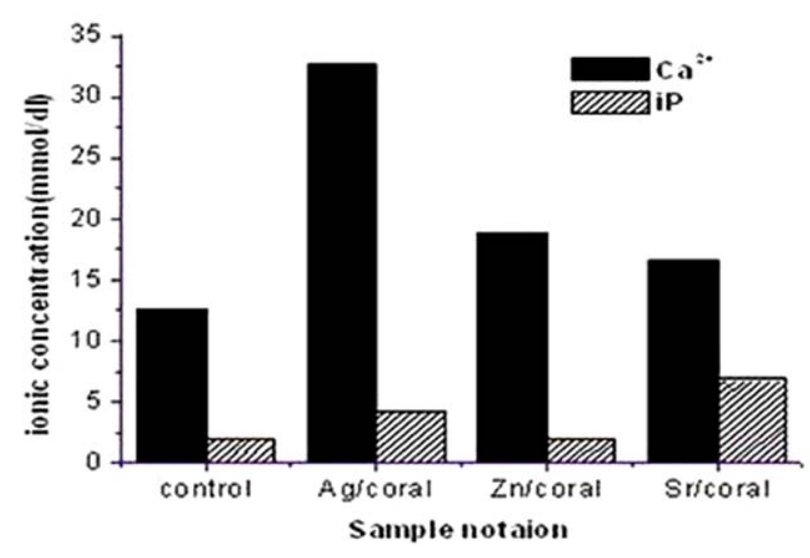

(b)

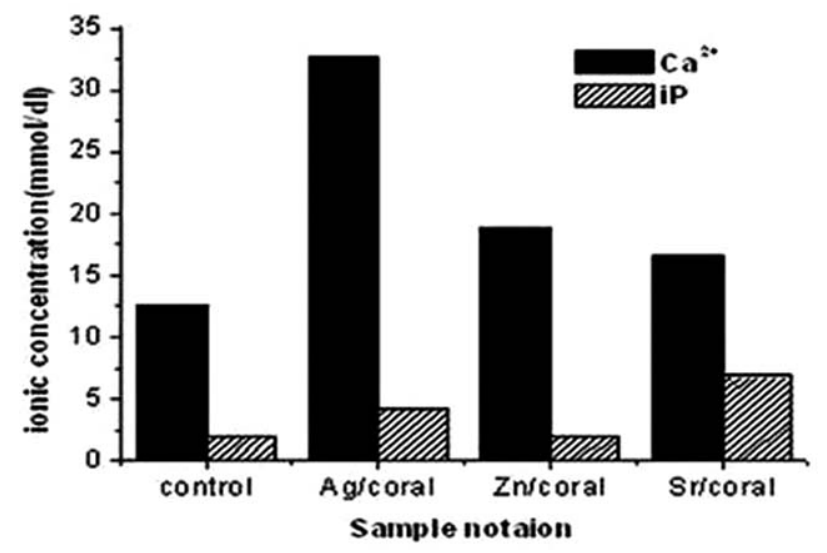

Fig. (5). (a) Calcium /phosphorous ratio $(\mathrm{Ca} / \mathrm{iP})$ and (b) the activity product [Ca] [iP], of physiological solutions.

In Saline as $\mathrm{Ca} / \mathrm{iP}$ ratios follow an order of $\mathrm{Ag}>\mathrm{Zn}>$ control corals whose corresponding values are 1 . $96>1.53>1.25$ respectively, being higher than 1 , therefore, all are expected to induce transformation of the formed surface amorphous calcium phosphate (ACp)to hydroxyl apatite (HA) (Fig. 5a). However, for $\mathrm{Sr} /$ coral having $\mathrm{Ca} / \mathrm{iP}$ ratio of 0.87 which is less or equal to 1 , the expected phase will be a mixture of HA and brushite $[17,18]$

In $\mathrm{SBF}$ all the samples released $\mathrm{Ca}^{2+}$ and iP ions to SBF post $72 \mathrm{~h}$ immersion. The values of $\mathrm{Ca} / \mathrm{iP}$ ratio are higher than 1, therefore, all phases will transform from amorphous calcium phosphate (ACp) to hydroxyapatite (HA) following the order of $\mathrm{Zn}>\mathrm{Ag}>$ control $>\mathrm{Sr} /$ corals having $\mathrm{Ca} / \mathrm{iP}$ ratios of $7.83>6.23>5.16>1.95$ respectively.

According to the non-classical nucleation theory [19], at given activity product $\left[\mathrm{Ca}^{2+}\right][\mathrm{iP}]$, rapid amorphous nucleation occurs at higher $\mathrm{Ca} / \mathrm{iP}$ ratio while slow one occurs at lower ratio. Therefore, slowest nucleation of 


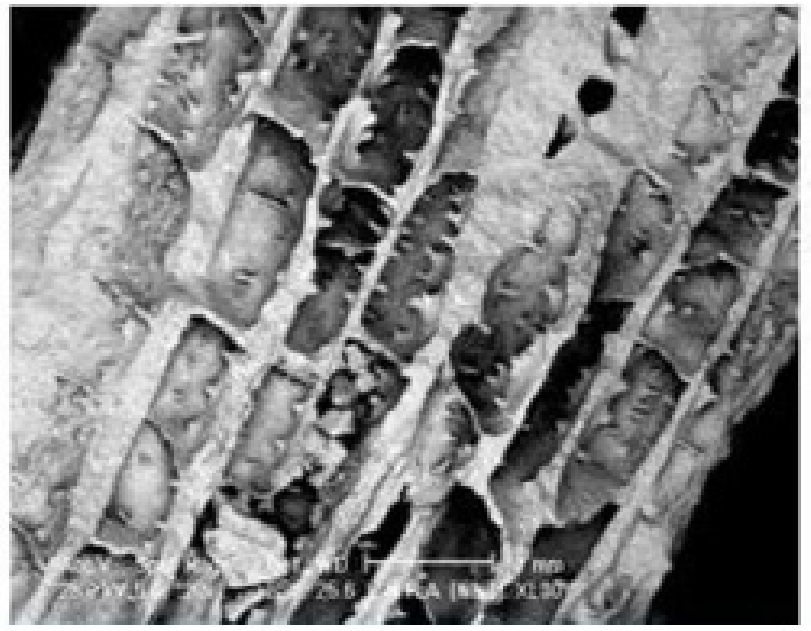

(a)

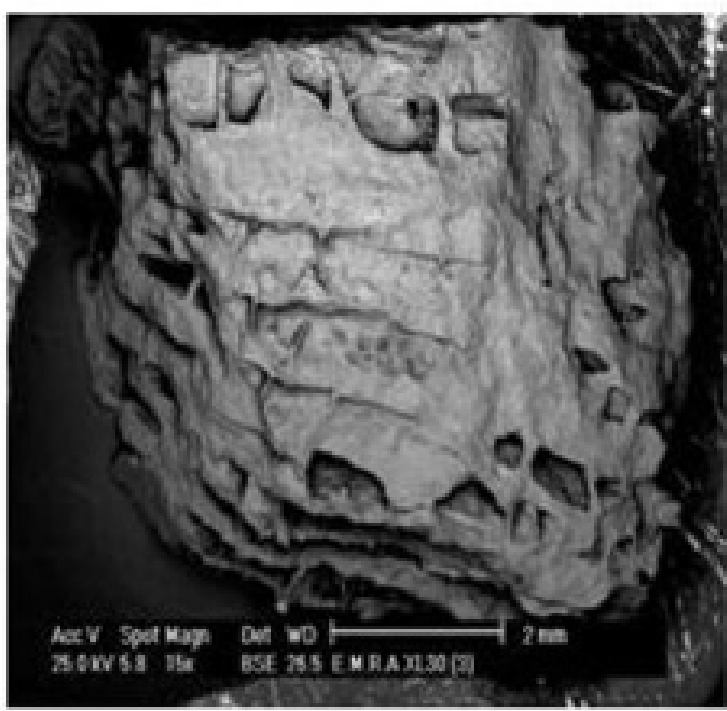

(c)

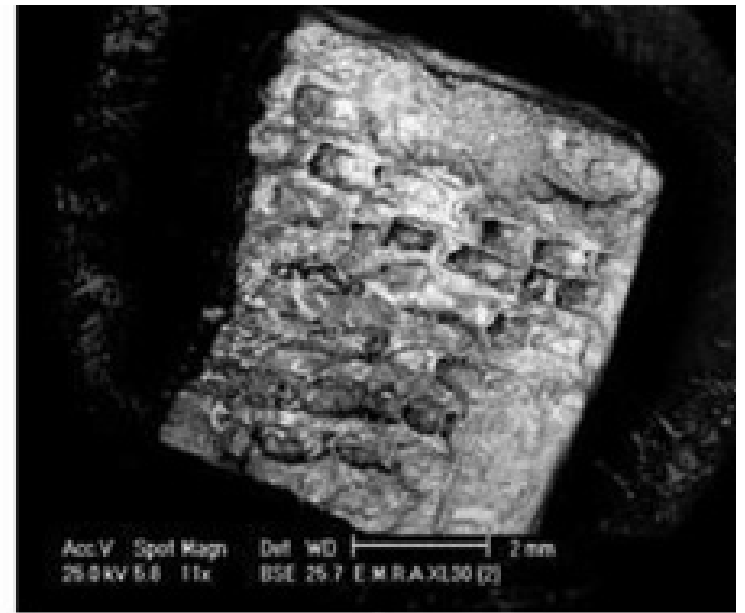

(b)

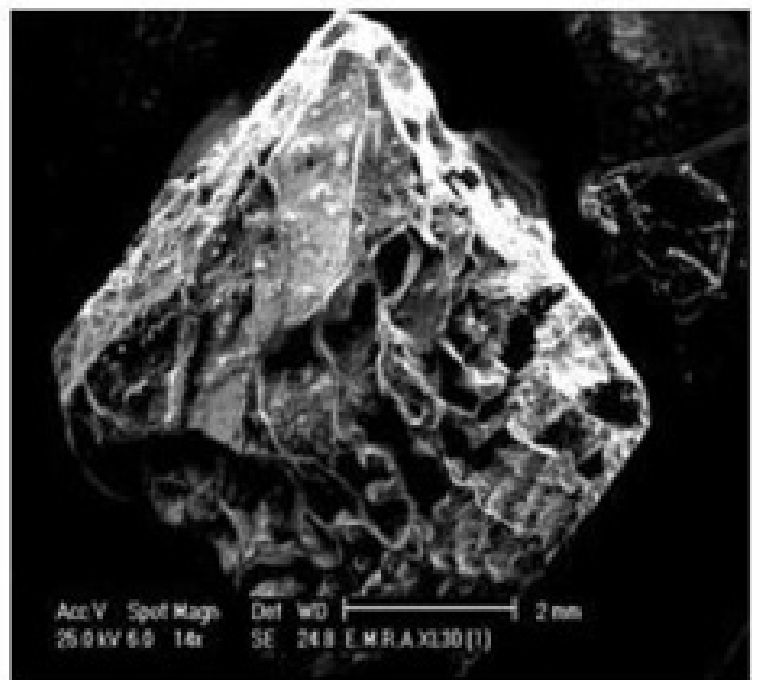

(d)

Fig. (6a-d). The whole skeleton of a)Control impregnated coral, b)Ag/coral, c)Zn/coral, d)Sr/coral.

apatitic layer is expected for $\mathrm{Sr} / \mathrm{Coral}$ whose activity product $\left[\mathrm{Ca}^{2+}\right][\mathrm{iP}]$ is 1.95 , while highest process is expected for $\mathrm{Zn} /$ coral having a value of 7.83 (Fig. 5b).

Additionally, at high activity product [Ca] [iP] nucleation would be homogeneous as for $\mathrm{Ag} / \mathrm{coral}$ which amounts to 0 . $1 \times 10^{-6} \mathrm{M}^{2}$ while heterogeneous direct nucleation could occur as for $\mathrm{Zn} /$ coral compared to $\mathrm{Sr} /$ Coral having 0.02 and $0.08 \times 10^{-6} \mathrm{M}^{2}$ respectively.

\subsubsection{Morphological Features}

Scanning Electron Microscope (SEM) examination of corals skeleton having $17 \%$ porosity and impregnated with the same concentration 2 moles of different ions ( $\mathrm{Ag}, \mathrm{Zn}$ and Sr) are shown in (Figs. 6-9) respectively.
At bar width of $2 \mathrm{~mm}$, the whole skeletons of the mentioned samples are shown for each ion (Fig. 6a-d). At such magnification it is clear that all of them become coated compared to control with several precipitations especially inside the chambers which become nearly closed covering original spines.

\subsection{3.a.Ag / Coral}

For Ag / coral sample, there is massive crystallization on the septum of coral chambers. Also there are several types of cubes inside chambers with massive crystallization and lines of depositions. The EDX of this crystallization reveals the presence of $\mathrm{Ca}, \mathrm{Ag}$ and $\mathrm{Cl}$ (Fig. 7a). At the same magnification, in another area there are several forms of 
(a)

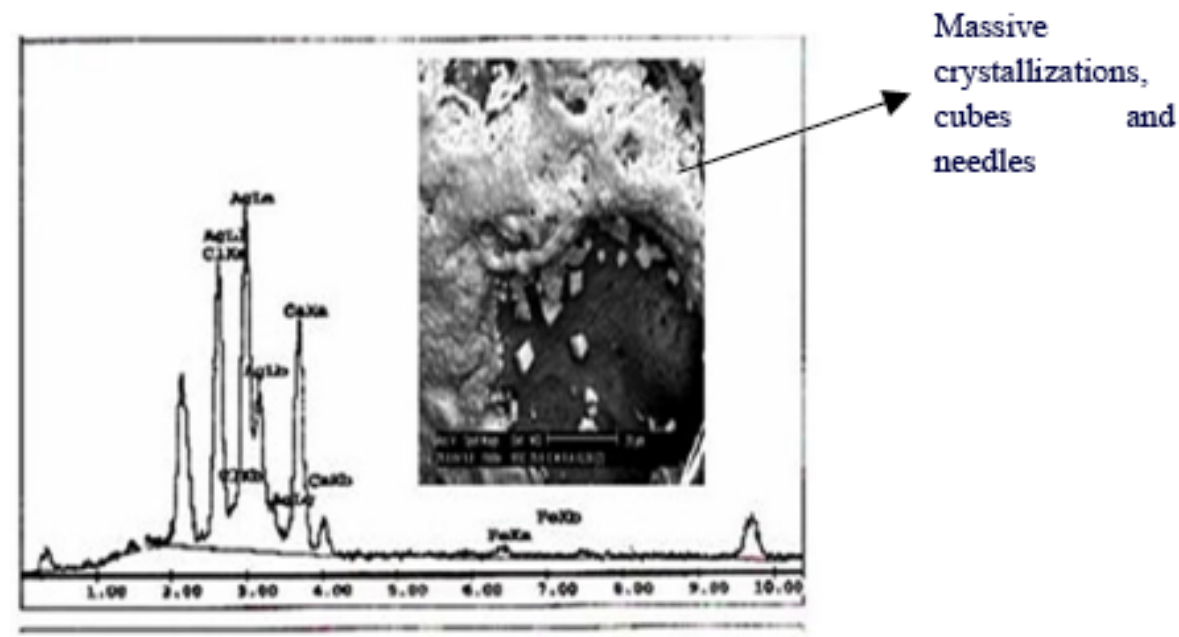

(b)

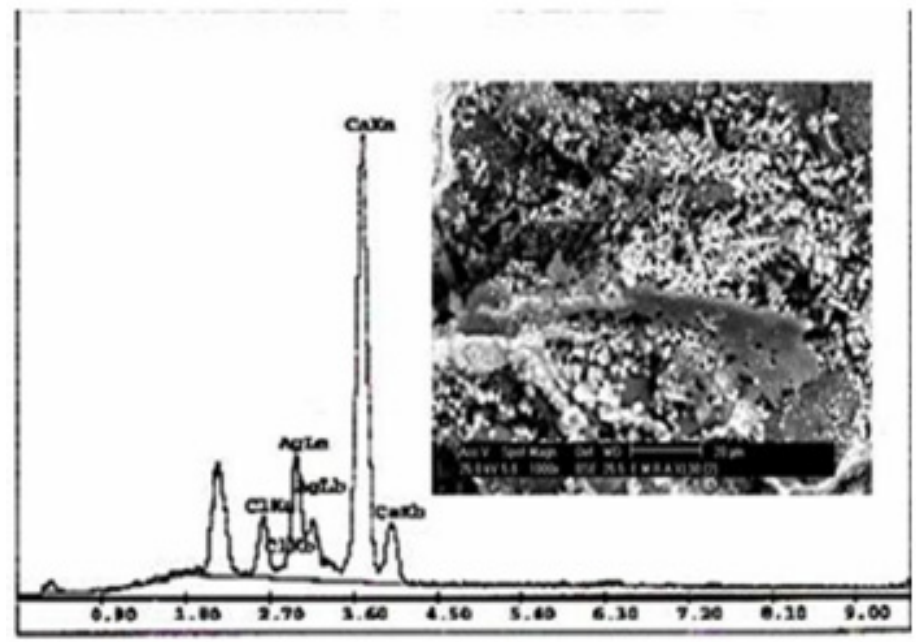

(c)

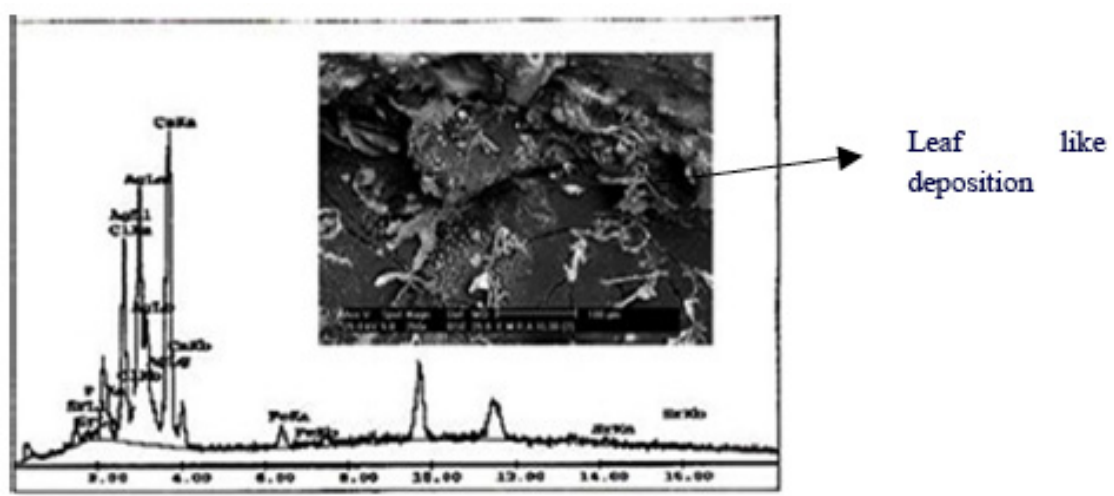

Fig. (7). SEM and EDX of Ag/coral (a) and (b) show massive crystallizations, cubes and needles, (c) leaf like deposition, trace of P, Fe and Sr from parent coral.

crystallization of cubes and needles (Fig. 7b). The EDX of this area reveal the presence of $\mathrm{Ca}, \mathrm{Ag}$ and $\mathrm{Cl}$ while elemental $\mathrm{Fe}$ is present as a trace element. The presence of elemental chloride is due to cleaning with $\mathrm{NaOCl}$ while the elemental $\mathrm{Fe}$ is from the structure of the parent coral. Fig. (7c) shows streaks or leaflets of deposition and is full with cracks due to solution treatment. The EDX of this area reveals the presence of $\mathrm{Ca}, \mathrm{Ag} . \mathrm{P}, \mathrm{Fe}, \mathrm{Sr}$ and $\mathrm{Cl}$ which indicate that not all $\mathrm{Ag}$ is released from coral but still present some in phosphate compounds from SBF. Other elements of $\mathrm{P}, \mathrm{Fe}$ and $\mathrm{Sr}$ are representing the original coral. From these results, it is clear that the samples are enriched with $\mathrm{Ca}$ and Ag. 


\subsection{3.b.Zn / Coral}

$\mathrm{Zn}$ / coral sample, shows different types of crystallization which is compact and oriented parallel to the surface. Another morphology is spongy and perpendicular to surface (Fig. 8a). These parallel crystals and some plates on the septum are magnified in Fig. (8b).

(a)

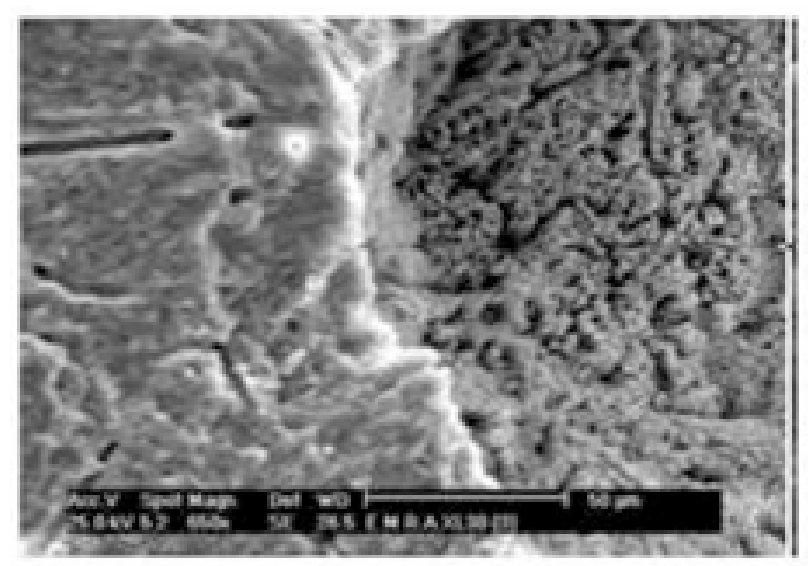

(b)

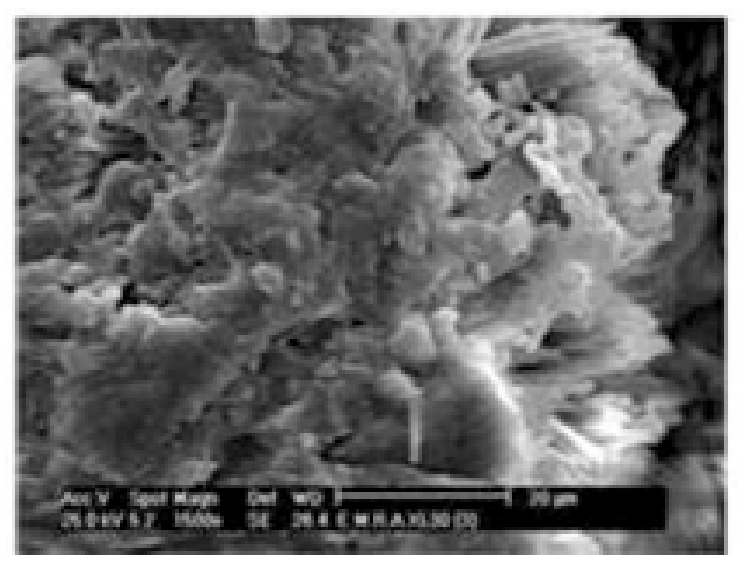

Fig. (8). SEM of $\mathrm{Zn} / \mathrm{Coral} \mathbf{a}$ and $\mathbf{b}$.

\subsection{3.c.Sr / Coral}

$\mathrm{Sr}$ / coral sample, (Fig. 9a), inside the chamber shows $\mathrm{Ca}$ phosphate rose shapes, and the surface is full of pores denoting the dissolution of some of the formed layer by prolonged soaking in SBF. The EDX of this area revealed the presence of $\mathrm{Ca}$ and minor amount of Sr. The presence of $\mathrm{Sr}$ is originating also from parent coral having aragonite structure [12] beside impregnation with $\mathrm{Sr}^{2+}$.

Another area with longitudinal parallel and inclined needles underneath a large mass full of rounded pores due to dissolution along with cracks is shown in Fig. (9b). The EDX of this area reveales the presence of $\mathrm{Ca}$ and minor amounts of $\mathrm{Sr}$.

During early immersion in SBF values of conductivity increase in the order of $\mathrm{Sr}^{2+}>\mathrm{Zn}^{2+}>\mathrm{Ag}^{+}$coral samples and saturation levels are recorded at 21,30 and $45 \mathrm{~h}$ respectively. Minimum values are recorded by $\mathrm{Zn} /$ coral while maximum ones are recorded by $\mathrm{Sr} /$ coral, although, the $\mathrm{Zn} /$ coral sample started like $\mathrm{Sr} /$ coral then decreased gradually to reach $\mathrm{Ag} /$ coral at $39 \mathrm{hrs}$ of measurements. This could be related to the different sizes of the ions involved having sizes of 194,
165, 142 and $219 \mathrm{pm}$ for $\mathrm{Ca}^{2+}, \mathrm{Ag}^{+}, \mathrm{Zn}^{2+}$ and $\mathrm{Sr}^{2+}$ respectively which would affect surface exchange processes.

In saline, an increase of $\mathrm{Ca}^{2+}$ concentrations in an order parallel to $\mathrm{Ag}^{+}>\mathrm{Zn}^{2+}>\mathrm{Sr}^{2+} /$ corals are recorded. The $\mathrm{Sr} /$ coral records peculiar trend of minimum increase of $\mathrm{Ca}$ but accompanied by maximum increase in $\mathrm{iP}$.

The SBF of Sr/coral records maximum value of iP which should account for its involvement in a compound forming and minimum increase of $\mathrm{Ca}$. The order of highest release and concentration of $\mathrm{Ca}$ in $\mathrm{SBF}$ is parallel to of $\mathrm{Ag},>\mathrm{Zn}$ coral. The depletion of $\mathrm{Ag}, \mathrm{Sr}$ or $\mathrm{Zn}$ ions is in favour of antibacterial and antimicrobial effects of the corals beside enhancement of the bone formation.

The values of $\mathrm{Sr}, \mathrm{iP}$ and $\mathrm{Ca}^{2+}$ in the treated parent coral are $0.7,0.5$ and 39.7 respectively, as measured by spectrophotometer which would account for the high released $\mathrm{Ca}^{2+}$ in Saline and SBF solutions.

The released ions in saline are $0.35,0.31$ and $0.22 \mathrm{mg}$ for $\mathrm{Ag}, \mathrm{Zn}$ and $\mathrm{Sr}$ respectively proving release in the same order from corresponding coral samples which would reduce its conductivity. However, conductivity values followed opposite trend. In SBF, the values of released ions are lower being $0.30,0.21$ and $0.17 \mathrm{mg}$ for the same order. Therefore, some of these ions are involved in the process of surface deposition of respective compounds or incorporated in phosphate phases

Silver ions have long been known to have powerful antibacterial activity [20], and the antibacterial activity is against Gram-negative Escherichia Coli (E. coli, ATCC25922) and Gram positive Staphlococcus aureus (S. aureus, ATCC6538). Striking features of Ag are reflected by clinical studies with silver based coating on medical devices. Bacteria are quite susceptible to Ag with bactericidal activity reported at $\mathrm{Ag}$ concentration as low as 35ppb [21].

Zinc was reported to have osteoconductive properties [22] and have direct stimulatory effect on bone mineralization in vitro and bone protein synthesis [22, 23]. Yamaguchi et al. reported an increase in protein synthesis in bone cells inducing bone formation [23].

Strontium has been reported to contribute to increase bone mass and volume when given at low doses, remineralizing skeletal lesions [24]. It seems that $\mathrm{Sr}$ directly suppresses bone resorption and has no deleterious effect on bone mineralization [25]. It was reported to have beneficial effects on bone formation in humans which results in increase trabecular volume [26]. The ionic strontium (Sr)in human, share the same physiologic pathway as calcium [27] and can be deposited into the mineral structure of the bone, especially in the regions of high metabolic turnover [28].

Nearly half century ago the beneficial affect of low doses of stable $\mathrm{Sr}$ in the treatment of osteoporosis, characterized by low bone mass, fracture risk and enhanced bone fragility was discovered [29]. The effect was attributed to preventation of bone loss by mechanical of depressing bone resorption and maintaining bone formation. According to Grynpas et al [30], the treatment with low doses of $\mathrm{Sr}$ increased the number of bone forming sites and vertebral bone volume in rats and showed no adverse effects on the mineral profile chemistry or bone matrix mineralization. 
(a)

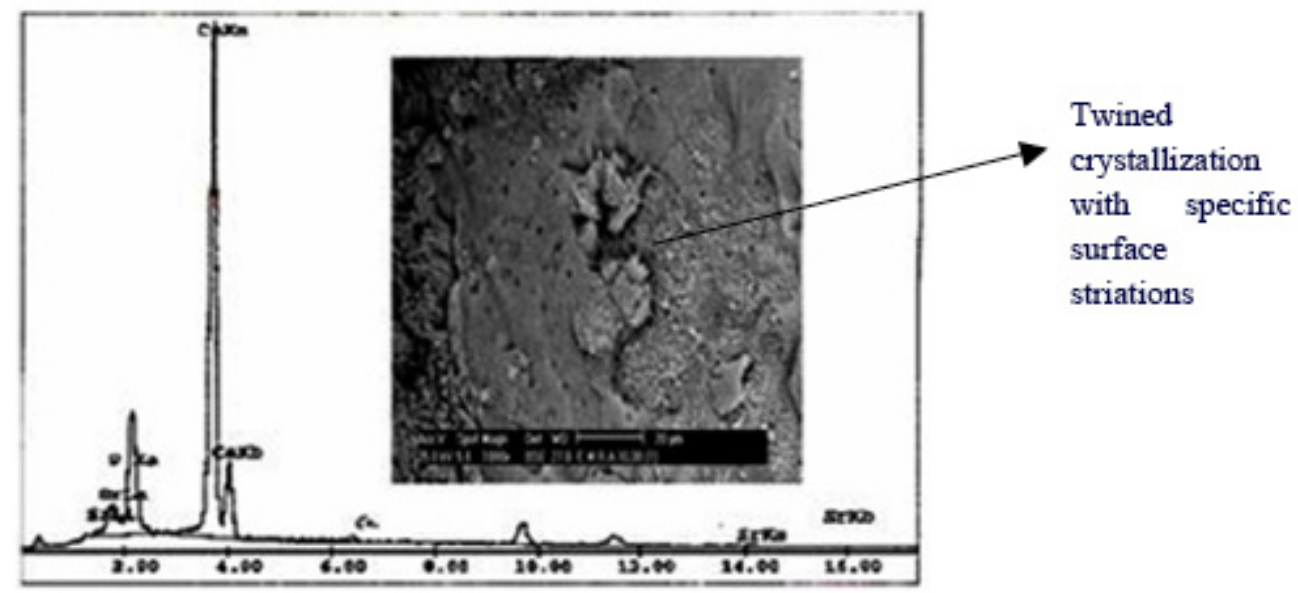

(b)

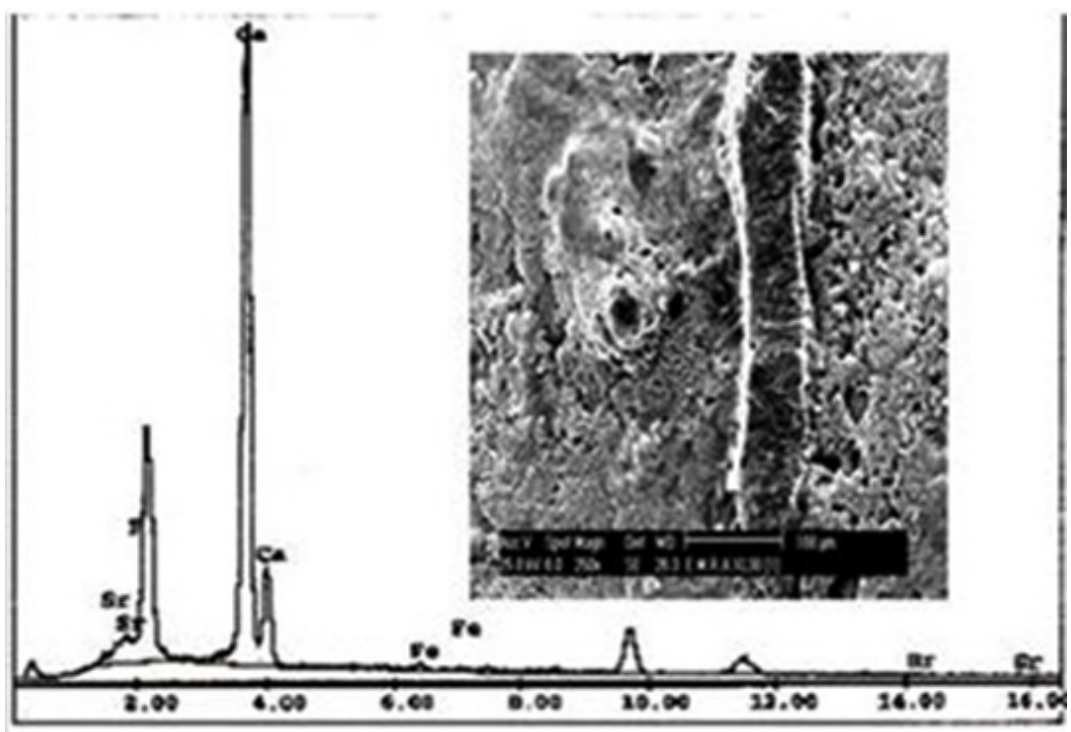

Fig. (9). (a) SEM and EDX of Sr/coral a: show twined crystallization (b) show longitudinal parallel inclined needles.

The conductivity values and trend are coinciding with those of biochemical data of SBF. The samples are possessing intermediate porosity of $17 \%$ with interconnectivity and architectures similar to bone. Therefore, they could be suitable for tissue engineered constructs that would possess antimicrobial effect and /or bone searching function to reduce implant infection and enhance bone formation especially with its natural architecture.

\section{CONCLUSIONS}

1- The conductivity values of saline proved dissolution in a reverse trend to SBF proving ionic deposition from the latter in favor biomimetic deposition.

2- As conductivity was saturated as early as $20 \mathrm{~h}$ for $\mathrm{Sr} /$ corals, the immersion for such time is recommended for biolayer deposition. Saturation was recorded at 32 and $45 \mathrm{hrs}$ for $\mathrm{Ag}$ and $\mathrm{Zn}$ respectively.

3- $\quad$ The presence of $\mathrm{Sr}^{2+}$ in corals lead to higher iP release from coral which would invite bone forming process involving $\mathrm{Ca}^{2+}$ precipitation.

\section{ACKNOWLEDGEMENTS}

The authors acknowledge the support of National Research Centre and Ain Shams University for the MSc program of Hadeer Ibraheem at biophysics dept., Faculty of Science, Cairo, Egypt.

\section{REFERENCES}

[1] http: //www. nof. org.

[2] Roy DM, Linnehan SK. Hydroxyapatite formed from coral skeletal carbonate by hydrothermal exchange. Nature 1974; 247: 220-2.

[3] Antonio JS, Olga PC, Rui LR. Bone tissue engineering: state of the art and future trends. Macromol Biosci 2004; 743: 765.

[4] Caroline D, Reggie HC, Karin C, Fatiha C, Maryam T, L'Hocine Y. Natural coral exoskeleton as a bone graft substitute. BioMed Mater Eng 2002; 12: 15-35.

[5] Kotani S, Fujita Y, Kitsugi T, Nakamuro T. Bone bonding mechanism of ß-TCp. J Biomed Mater Res 1991; 25: 1303.

[6] Fujita Y, Yamamuro T, Nakmum T, Kotani S. The bonding behaviour of calcite bone. J Biomed Mater Res 1991; 25: 991.

[7] Ohtsuki C, Aoki Y, Kokubo T, Fujita Y, Kotani S, Yamamuro T. Bioactivity of limestone and abalone shell. Transaction of the $11^{\text {th }}$ annual meeting of Japan Society for Biomaterials. Japan: Toshima-KU, Tokyo 1989; p. 12. 
[8] Kim TM, Feng QL, Kim JO, Wang H, Chen GC, Cui FZ. Antimicrobial effects of metal ions $(\mathrm{Ag}, \mathrm{Cu}, \mathrm{Zn})$ in hydroxyapatite. Mater med 1998; 9: 129-34.

[9] Abou Neel EA, Ahmed I, Prattern J, Nazhat SN, Knowles JC. Characterization of antibacterial copper releasing degradable phosphate glass fibers. Biomaterials 2005; 26: 2247-54.

[10] Heidenau F, Mittelmeier W, Detsch R, et al. A novel antibacterial titania coating: Metal ion toxicity and in vitro surface colonization. Mater Med 2005; 16: 883-8.

[11] Ibrahim H, MSc. Thesis, Awarded. Egypt: Ainshams University 2007.

[12] Kokubo T. Bioactive glass ceramics: properties and applications. Biomaterials 1991; 12: 155 .

[13] KoKubo. Proceeding of the $3^{\text {rd }}$ Euro-ceramics Conference Novel Ceramics for Biomedical Applications, Spain 1993; 3: 1-16

[14] Kokubo T, Takadama H. How useful in SBF in predicting in vivo bone bioactivity. Biomaterial 2006; 27: 2907

[15] Abdel-Fattah WI, El-Bassyouni GT, Ibrahim H. Biomimetic coating of corals treated with sodium hypochlorite compared to calcium hypochlorite. Egypt. J Biomed Sci 2008; 27: 12.

[16] Prough DS, Bidani A. Hyperchloremic metabolic acidosis is a predictable consequence of intraoperative infusion of $0.9 \%$ saline. Anesthesiology 1990; 90: 1247-49.

[17] Frances MD. Solubility behaviour of dental enamel and other Calcium phosphates. Ann NY Acad Sci 1965; 131: 694.

[18] Cheng P, Kenneth PH. Solution $\mathrm{Ca} / \mathrm{iP}$ ratio affects calcium phosphate crystal phases. Calcif Tissue Int 1983; 35: 596.

[19] Jears G W. The origin of spherulites. J Phys chem 1961; 65: 1738.
[20] Hyung-Jun J, Sung-Chul YI, Seong-Geun Oh. Preparation and antibacterial effects of $\mathrm{Ag}-\mathrm{Sio}_{2}$ thin films by sol-gel method. Biomaterials 2003; 24: 4921.

[21] Chambers C, Proctar C, Kabler P. Bacterial effect of low concentration of silver. J Am Water Works Assoc 1962; 54: 208.

[22] Yamaguchi M, Goa YH. Zinc enhancement of genistein's anabolic effect on bone components in elderly female rats. Gen pharmaco 1988; 38(3): 199-202.

[23] Eberle J, Schmidmayzr S, Erbzn RG, Stangassinger M, Roth HP. Skeletal effects of zinc deficiency in growing rats. J Trace Elem Med Biol 1999; 13: 21-6.

[24] Grynpas MD, Marie PJ. Effects of low doses of strontium on bone quality and quantity in rats. Bone 1990; 11(5): 313-9.

[25] Marie PJ, Gabra MT, Hott M, Miravat L. Effect of low doses of stable stronium on bone metabolism in rats. Miner Electrolyte Metal 1985; 11: 5-13

[26] Sobel AE, Cohen Y, Kramer B. The nature of the injury to the calcifying mechanism in rickets and calcification in strontium rickets. Biochem J 1935; 29: 2640-45

[27] Blake GM, Zivonovic MA, Mcewan AJ. Sr kinetics in metastatie bone disease. J Nucl Med 1986; 27: 1030

[28] Blake GM, Zivonovic MA, Mcewan AJ. Strontium kinetics in disseminated carcinoma of the prostate. Eur J Nucl Med 1986; 12: 447.

[29] Shorr E, Carter AC. The usefulness of strontium as an adjuvant to calcium ion in the remineralization of the skeleton in man. Bull Hosp Joint Dis Orthop Inst 1952; 13: 59.

[30] Grynpas MD, Hamilton E, Cheung R. Strontium increases vertebral bone volume in rats at a low dose that does not induce detectable mineralization defect. Bone 1996; 18: 253.

(C) Abdel-Fattah et al.; Licensee Bentham Open.

This is an open access article licensed under the terms of the Creative Commons Attribution Non-Commercial License (http://creativecommons.org/licenses/by$\mathrm{nc} / 3.0 /$ ) which permits unrestricted, non-commercial use, distribution and reproduction in any medium, provided the work is properly cited. 